\title{
Clinical Profile of Patients with Diabetic Foot Ulcer Treated Conservatively or Surgically and Effect of Risk Factors on Ulcer Healing
}

\author{
Ved Prakash
}

Associate Professor, Department of Endocrinology, Indira Gandhi Institute of Medical Science, Patna, Bihar.

\begin{abstract}
Objective: The aim of this study was to assess the clinical profile of patients with diabetic foot ulcer treated conservatively or surgically and effect of risk factors on ulcer healing.

Methods: This was a retrospective observational study conducted in tertiary medical teaching hospital where medical records of diabetic patients who were admitted with foot problem were evaluated. All diabetic patients who were aged $>18$ years and admitted with DFU were included in this study. A structured proforma was used to collect data from the medical record. SPSS version 20.0 was used to perform the statistical analysis.
\end{abstract}

Result: 280 subjects with diabetic foot ulcer (DFU) were evaluated in this study. $71 \%$ ulcers were healed where as $11 \%$ were persisted unhealed. Patients who were undergone for amputation $12 \%$ were minor (Foot only) and $4 \%$ were major (above the ankle). A statistically significant association between age, duration of diabetes, glycemic control peripheral neuropathy, and ulcer size were found with diabetic foot ulcer healing.

Conclusion: Modifiable factors like good glycemic control, early management of ulcers and early treatment of peripheral neuropathy can influence Diabetic foot ulcer outcomes. Special care should be provided to diabetic subjects who are aged and have longer duration of diabetes.

Keyword: Diabetic foot ulcers, ulcer severity, clinical profile, Wagner's Classification, outcome

\section{INTRODUCTION}

In India 4\%-11.6\% in urban and $2.4 \%$ in rural dwellers were affected with a common disease called diabetes ${ }^{[1]}$. Foot complications from simple calluses to major abscesses and osteomyelitis were developed in approximately $10 \%-25 \%$ of all diabetics subjects. As compare to non diabetic subjects had 40 times higher chance of leg amputation and $50 \%$ of the diabetic subjects who had 1st leg amputation were undergo second leg too within 5 years ${ }^{[2]}$. Heavy expenses, loss of productive time and often unbearable suffering pain are associated with diabetic foot ulcer (DFU) ${ }^{[3]}$ and accompanying neuropathy further worsen the situation and can led to limb amputation [4].

In India poverty, poor sanitation, poor hygiene, lack of basic medical infrastructure, lack of knowledge regarding diabetic foot and habits like walking barefooted have further worsened the problem. In most of the diabetic care centre in India still diabetic foot care still used to avoid amputation thus from the very beginning the proper foot care and the awareness were generally missing which lead to increase in more frequent presentation of the cases in referring hospitals.

Thus despite a life threatening complication still foot care has received the same level of attention as other diabetes complications ${ }^{[5]}$. Still the initiation of current research clinical characteristic in foot ulcers among diabetic patients and its healing outcome were not properly studies in highly dense eastern Indian diabetic populations. The aim of this study was to 
assess (1) the clinical profile of patients with diabetic foot ulcer treated conservatively or surgically and (2) effect of risk factors on ulcer healing and also for further improvement in diabetic foot management which may become a reference.

\section{METHODS}

Study design: This was a retrospective observational study conducted in tertiary medical teaching hospital where medical records of diabetic patients who were admitted with foot problem were evaluated. The study was conducted among patients who were admitted over a 3 years periods from January 2017 to December 2019 and were mostly referred from the rural hospitals. As this retrospective study evaluated de-identified data and involved no potential risk to patients, requirement to obtain written informed consent was waived off. Ethical clearance was obtained from the Institutional Review Board. For the sake of privacy and confidentiality no personal identifiers (names, address and any private information) was not collected. Data was anonyms and handled confidentially during all phases of research activities. This study was conducted in accordance with the Declaration of Helsinki.

Population: The final sample size of the population was calculated to be 280 considering 95\% confidence level and a $4 \%$ margin of error and almost 13-15\% prevalence of diabetic foot ulcer in India $[6,7]$.

Eligibility Criteria: All diabetic patients who were aged $>18$ years and admitted with DFU were included in this study. Any patient clinically suspected with incidental ulcers, having Charcot foot and traumatic amputations were excluded along with gestational diabetic and patients who were seriously ill.

Treatment settings: All patients were individually monitored during their hospital stay regarding hypoglycemia and medical dose adjustment was done as per requirement and decoration of treating physician. When there were clinical signs of infection, antibiotic was instituted. Diabetic people who were presented with nontraumatic lesions of the skin on the foot distal to malleoli were considered as diabetic foot ulcer. For evaluation of ulcers, Wagner's classification for diabetic foot was used. At discharge when previously open wound were covered by continuous viable epithelial were defined as healed. In other hand incomplete re-epithelialization of the wound were defined as persisting unhealed. Amputations restricted to the foot were defined as minor amputation where as any other amputation took place above the levels of the ankle were defined as major amputation.

Data Analysis: A structured proforma was used to collect data from the medical record. SPSS version 20.0 was used to perform the statistical analysis. As counts and percentages, the data were reported, and the level of significance is set at $p<0.05$. To test for correlations between variables, the $\chi^{2}$ test and Fisher's exact test were used. Multiple logistic regression model were used to assess the effect of risk factors on ulcer healing.

\section{RESULTS}

Clinical and demographic features of the participating patients were summaries in table $1.46 .3 \pm 16.4$ years were the mean age of the patients and $96 \%$ were having type 2 diabetes and $61 \%$ of the population were either obese or overweight. $68 \%$ of the population were having long duration of diabetes ( $>5$ years of duration). Almost all patients were in medication. $39 \%$ of patients were also having co-morbid hypertension and peripheral neuropathies were documented with $63 \%$ patients. Different type of foot ulcers were observed at presentation among which in 120 (43\%) patients it were pure neuropathic, $31(11 \%)$ 
Ved Prakash. Clinical profile of patients with diabetic foot ulcer treated conservatively or surgically and effect of risk factors on ulcer healing.

patients it were ischemic-type, while 84 $(30 \%)$ it were neuro-ischemic origin.

Table 1: Basic characteristics of the participants

\begin{tabular}{|c|c|c|}
\hline Variables & Category & $\mathrm{N}(\%)$ \\
\hline \multirow[t]{2}{*}{ Sex } & Male & $171(61 \%)$ \\
\hline & Female & $109(39 \%)$ \\
\hline \multirow[t]{3}{*}{ Age } & $<30$ & $32(11 \%)$ \\
\hline & $30-50$ & $140(50 \%)$ \\
\hline & $>50$ & $108(39 \%)$ \\
\hline \multirow[t]{3}{*}{ BMI } & Normal & $110(39 \%)$ \\
\hline & Overweight & $93(33 \%)$ \\
\hline & Obese & $77(28 \%)$ \\
\hline \multirow{2}{*}{ Type of DM } & Type 1 & $12(4 \%)$ \\
\hline & Type 2 & $268(96 \%)$ \\
\hline \multirow{3}{*}{$\begin{array}{l}\text { Duration of } \\
\text { DM }\end{array}$} & $<5$ years & $89(32 \%)$ \\
\hline & 5 to 10 years & $99(35 \%)$ \\
\hline & $\geq 10$ years & $92(33 \%)$ \\
\hline \multirow[t]{4}{*}{ HbA1c (\%) } & $<7$ (good control) & $11(4 \%)$ \\
\hline & 7.1-8\% (fair control), $n(\%)$ & $35(12 \%)$ \\
\hline & $8.1-10 \%$ (poor control), $n(\%)$ & $67(24 \%)$ \\
\hline & $>10 \%$ (very poor control), $n(\%)$ & $167(60 \%)$ \\
\hline \multirow{4}{*}{$\begin{array}{l}\text { Treatment of } \\
\text { DM }\end{array}$} & Oral Antidiabetic & $98(35 \%)$ \\
\hline & Insulin & $104(37 \%)$ \\
\hline & Combined & $76(27 \%)$ \\
\hline & No Treatment & $2(1 \%)$ \\
\hline \multirow{2}{*}{$\begin{array}{l}\text { Comorbid } \\
\text { hypertension }\end{array}$} & Yes & $108(39 \%)$ \\
\hline & No & $172(61 \%)$ \\
\hline \multirow{2}{*}{$\begin{array}{l}\text { Periphral } \\
\text { Neuropathy }\end{array}$} & Present & $176(63 \%)$ \\
\hline & Absent & $104(37 \%)$ \\
\hline \multirow[t]{4}{*}{ Type of ulcer } & Pure neuropathic, & $120(43 \%)$ \\
\hline & Pure ischemic, & $31(11 \%)$ \\
\hline & Neuroischemic, & $84(30 \%)$ \\
\hline & Non-classified, & $45(16 \%)$ \\
\hline \multirow[t]{3}{*}{ Ulcer Size } & $<1 \mathrm{~cm}$ & $132(47 \%)$ \\
\hline & $1-5 \mathrm{~cm}$ & $128(46 \%)$ \\
\hline & $>5 \mathrm{~cm}$ & $20(7 \%)$ \\
\hline
\end{tabular}

Distributions of foot lesion in accordance with Wagner grading system at presentation were summaries in table 2 . In this retrospective study, it were observed that majority of patients were in grade 2 (38\%) and grade $3(22 \%)$.

Disarticulation (23\%) and

Debridement $(21 \%)$ were the most common procedure to treat DFU in this study.
Treatment modalities were summarise in table 3 .

Table 2: Distribution of foot lesion in accordance with Wagner grading system at presentation.

\begin{tabular}{|l|l|l|}
\hline $\begin{array}{l}\text { Wagner } \\
\text { grade }\end{array}$ & Signs & N (\%) \\
\hline 0 & No ulcer in a high-risk foot & 0 \\
\hline 1 & $\begin{array}{l}\text { Superficial ulcer involving the full skin } \\
\text { thickness }\end{array}$ & $\begin{array}{l}51 \\
(18 \%)\end{array}$ \\
\hline 2 & $\begin{array}{l}\text { Deep ulcer penetrating to } \\
\text { ligaments/muscle, but no bone } \\
\text { involvement or abscess formation }\end{array}$ & $\begin{array}{l}106 \\
(38 \%)\end{array}$ \\
\hline 3 & $\begin{array}{l}\text { Deep ulcer with cellulitis or abscess } \\
\text { formation, often with osteomyelitis }\end{array}$ & $\begin{array}{l}62 \\
(22 \%)\end{array}$ \\
\hline 4 & $\begin{array}{l}\text { Localized gangrene } \\
40 \\
(14 \%)\end{array}$ \\
\hline 5 & $\begin{array}{l}\text { Extensive gangrene involving the whole } \\
\text { foot }\end{array}$ & $\begin{array}{l}16 \\
(6 \%)\end{array}$ \\
\hline Missing data not stated & $5(2 \%)$ \\
\hline Total & & 280 \\
\hline
\end{tabular}

Table 3: Treatment modalities in the present study.

\begin{tabular}{|l|l|}
\hline Treatment Type & No of Patients (N\%) \\
\hline Conservative & $46(16 \%)$ \\
\hline Debridement & $60(21 \%)$ \\
\hline Disarticulation & $63(23 \%)$ \\
\hline Fasciotomy & $34(12 \%)$ \\
\hline Debridement + Fasciotomy & $8(3 \%)$ \\
\hline Debridment + SSG & $38(14 \%)$ \\
\hline I and D & $16(6 \%)$ \\
\hline Minor Amputation & $14(5 \%)$ \\
\hline Major Amputation & $1(0 \%)$ \\
\hline
\end{tabular}

Association between $\mathrm{HbA1c}$ and outcome of diabetic foot ulcers after discharge were summarises in table 4. Regarding the relation between DFU an HbA1c, patients who were achieved good glycemic control, i.e. HbAlc $\leq 7 \%$, had a $100 \%$ healing rate (table 4 ). Whereas the healing rate was only $52 \%$ among subjects whose $\mathrm{HbA1c}$ were still in higher grade (i.e., $>7 \%$ ) and the difference were statistically significant $(\mathrm{p}=0.007)($ table 4$)$.

Table 4: Association between Age, duration of diabetes, HbA1c, peripheral neuropathy, ulcer size and outcome of diabetic foot ulcers after discharge.

\begin{tabular}{|c|c|c|c|c|c|c|c|c|c|c|c|c|c|c|c|c|c|c|}
\hline \multirow[t]{2}{*}{ Category } & \multicolumn{4}{|l|}{ Age } & \multicolumn{4}{|c|}{ Duration of Diabetes } & \multicolumn{3}{|c|}{ HbA1c (\%) } & \multicolumn{3}{|c|}{ Peripheral Neuropathy } & \multicolumn{4}{|c|}{ Ulcer Size } \\
\hline & $\begin{array}{l}<30 \\
(\mathrm{~N}= \\
32)\end{array}$ & $\begin{array}{l}30-50 \\
(\mathrm{~N}= \\
140)\end{array}$ & $\begin{array}{l}>50 \\
(\mathrm{~N}= \\
108)\end{array}$ & $\begin{array}{l}P \\
\text { value }\end{array}$ & $\begin{array}{l}<5 \\
\text { years } \\
(\mathrm{N}= \\
89)\end{array}$ & $\begin{array}{l}5 \text { to } \\
10 \\
\text { years } \\
(\mathrm{N}= \\
99)\end{array}$ & $\begin{array}{l}\geq 10 \\
\text { years } \\
(\mathrm{N}= \\
92)\end{array}$ & $\begin{array}{l}\mathrm{P} \\
\text { value }\end{array}$ & $\begin{array}{l}\leq 7 \\
\% \\
(\mathrm{~N}-25)\end{array}$ & $\begin{array}{l}>7 \% \\
(\mathrm{~N}=255)\end{array}$ & $\begin{array}{l}\mathrm{P} \\
\text { value }\end{array}$ & $\begin{array}{l}\text { Present } \\
(\mathrm{N}= \\
176)\end{array}$ & $\begin{array}{l}\text { Absent } \\
(\mathrm{N}=104)\end{array}$ & $\begin{array}{l}\mathrm{P} \\
\text { value }\end{array}$ & $\begin{array}{l}<1 \\
\mathrm{~cm} \\
(\mathrm{~N}= \\
132)\end{array}$ & $\begin{array}{l}1-5 \\
\mathrm{~cm} \\
(\mathrm{~N}= \\
128)\end{array}$ & $\begin{array}{l}5 \\
\mathrm{~cm} \\
(\mathrm{~N}= \\
20)\end{array}$ & $\begin{array}{l}\mathrm{P} \\
\text { value }\end{array}$ \\
\hline Healed & $\begin{array}{l}32 \\
(10 \mathrm{o} \%)\end{array}$ & $\begin{array}{l}118 \\
(84 \%)\end{array}$ & $\begin{array}{l}50 \\
(28 \%)\end{array}$ & 0.006 & $\begin{array}{l}89 \\
(100 \%)\end{array}$ & $\begin{array}{l}83 \\
(84 \%)\end{array}$ & $\begin{array}{l}28 \\
(30 \%)\end{array}$ & 0.0001 & $\begin{array}{l}25 \\
(100 \%)\end{array}$ & $\begin{array}{l}175 \\
(69 \%)\end{array}$ & 0.007 & $\begin{array}{l}96 \\
(54 \%)\end{array}$ & $\begin{array}{l}104 \\
(100 \%)\end{array}$ & & $\begin{array}{l}132 \\
(100 \%)\end{array}$ & $\begin{array}{l}68 \\
(53 \%)\end{array}$ & - & 0.001 \\
\hline $\begin{array}{l}\text { Persisting } \\
\text { unhealed }\end{array}$ & & $\begin{array}{l}14 \\
(10 \%)\end{array}$ & $\begin{array}{l}18 \\
(17 \%)\end{array}$ & 0.06 & - & $\begin{array}{l}11 \\
(11 \%)\end{array}$ & $\begin{array}{l}21 \\
(23 \%)\end{array}$ & 0.001 & - & $\begin{array}{l}32 \\
(12 \%)\end{array}$ & - & $\begin{array}{l}32 \\
(18 \%)\end{array}$ & - & & & $\begin{array}{l}32 \\
(25 \%)\end{array}$ & - & - \\
\hline $\begin{array}{l}\text { Minor } \\
\text { amputation }\end{array}$ & & $\begin{array}{l}8 \\
(6 \%)\end{array}$ & $\begin{array}{l}28 \\
(26 \%)\end{array}$ & 0.008 & - & $\begin{array}{l}2 \\
(2 \%)\end{array}$ & $\begin{array}{l}34 \\
(37 \%)\end{array}$ & 0.02 & - & $\begin{array}{l}36 \\
(14 \%)\end{array}$ & - & $\begin{array}{l}36 \\
(20 \%)\end{array}$ & - & & - & $\begin{array}{l}28 \\
(22 \%)\end{array}$ & $\begin{array}{l}8 \\
(40 \%)\end{array}$ & 0.02 \\
\hline $\begin{array}{l}\text { Major } \\
\text { amputation }\end{array}$ & & & $\begin{array}{l}12 \\
(11 \%)\end{array}$ & - & - & $\begin{array}{l}3 \\
(3 \%)\end{array}$ & $\begin{array}{l}9 \\
(10 \%)\end{array}$ & - & - & $12(5 \%)$ & - & $\begin{array}{l}12 \\
(7 \%)\end{array}$ & - & & - & - & $\begin{array}{l}12 \\
(60 \%)\end{array}$ & - \\
\hline
\end{tabular}

After applying multiple logistic regression he univariate statistical significance was maintained and the same were summarises in table 5 
Table 5: Multiple logistic regression model of the effect of risk factors on ulcer healing

\begin{tabular}{|l|l|l|l|}
\hline Risk Factor & Odds ratio & 95\% CI & P Value \\
\hline Age & 1.01 & $0.98-1.02$ & 0.19 \\
\hline Diabetes Mellitus duration & 0.93 & $0.76-1.06$ & 0.23 \\
\hline HbA1c & 0.96 & $0.82-1.1$ & 0.51 \\
\hline Peripheral neuropathy & 1.13 & $0.82-1.48$ & 0.62 \\
\hline Ulcer Size & 1.00 & $0.83-1.21$ & 0.94 \\
\hline
\end{tabular}

\section{DISCUSSION}

Majority of the patients were having type 2 diabetes, and belongs to middle age group $(50 \%) .37 \%$ of the patients were on insulin and $27 \%$ were on both oral and insulin combined treatment. High percentage of insulin was also correlated with heavy weight as $61 \%$ of the population were either obese or overweight. Similar high BMI were also noticed in few earlier studies among subjects who developed DFU ${ }^{[8]}$. It was already established by Klaphake et al [9] that amputation rate in diabetes subjects increase with age. Similarly in current study treatment outcome was poorest in $>50$ years age group.

For evaluation and management of diabetic foot ulcers best known method is consider as Wagner's classification mainly because of its simplicity in use. In current study $38 \%$ patients had Wagner classification grade II and occupied highest frequency. $42 \%$ of total subjects in current study were presented with higher Wagner classification grade (i.e., with grade 3,4 and 5) which clearly shows that subjects were presented at late stage with deep ulcer, with cellulitis or abscess formation, with osteomyelitis and even with frank gangrene of the foot. Thus the higher chance of sepsis may influence their poor treatment outcomes.

It has also documented that both Macrovascular and microvascular complications of diabetes are linked directly with duration of the disease ${ }^{[10]}$. In current observation $68 \%$ of the population were having long duration of diabetes ( $>5$ years of duration) at presentation. This findings were correlated with few previous studies ${ }^{[11,12]}$, where healing was very limited and maximum patients were ended up with minor or major amputation.
The current finding demonstrated that participants who had uncontrolled blood sugar having lesser success rate in treating DFU. Thus degree of glycemic control not only acts as a major risk factor for developing DFU but also plays a major role for its treatment success rate. Similar findings also documented in few previous studies ${ }^{[13,14]}$. Current study clearly shows that progression of major complications like DFU can be controlled if patients achieve optimal plasma glucose level.

In similar to the current observation few earlier studies ${ }^{[15,16]}$ also documented the strong relation of peripheral neuropathy with diabetic foot complications. If diabetic tic subjects were having peripheral neuropathy it further increase the duration of pressure and therefore produce repetitive trauma to the feet. Perhaps lack of awareness regarding foot care and presence of neuropathy were the the main cause of higher incidence of wound severity at presentation. As per few earlier studies the most common cause of foot ulceration were spontaneous blisters ${ }^{[17,18]}$ and use of inadequate footwear ${ }^{[19-21]}$. In current study at presentation $43 \%$ had pure neuropathic ulcer, where as $30 \%$ were neuroischemic. Similar findings were also documented by Thewjitcharoen et al. ${ }^{[21]}$ where they found that neuropathy was approximately $56.8 \%$ among diabetic subjects with diabetic foot ulcer and neuroischemic ulcers were present in another $29.3 \%$.

Fife et al, ${ }^{[22]}$ already demonstrate that ulcer size, wound age (duration in days), Wagner grade and number of concurrent wounds of any etiology please a crucial role for the wound healing of the patients. Even in current study $46 \%$ of the patients were having ulcer size of $1-5 \mathrm{~cm}$ and 75 were haven having ulcer of $>5 \mathrm{~cm}$.

Limitation of the study: Retrospective studies always have few limitations like review of medical records [23] and several missing variables. Apart of this hospital facilities or the physicians or surgeons decision may influence the treatment outcome. Single centre study was 
another limitation which warned the necessity for multicenter study in future towards further clarity. Author suggest a further research to address the important issues like level of awareness regarding foot ulcer and patients attitude to use preventive measure like use of proper footwear.

\section{CONCLUSION}

Modifiable factors like good glycemic control, early management of ulcers and early treatment of peripheral neuropathy can influence Diabetic foot ulcer outcomes. Special care should be provided to diabetic subjects who are aged and have longer duration of diabetes. During followup of patients with a history of peripheral neuropathy and ulceration, physician should thoroughly emphasis to prevent further severity of diabetic foot ulcer. There is an urgent need that right from the beginning of diabetes detection health care professionals should prioritised proper patients education regarding awareness and preventive measures.

\section{Acknowledgement: None}

Conflict of Interest: None.

Source of Funding: No funding was received from any organization.

\section{Ethical Approval: Approved}

\section{REFERENCES}

1. Connor H. Some historical aspects of diabetic foot disease. Diabetes Metab Res Rev. 2008 May-Jun;24 Suppl 1:S7S13. doi: 10.1002/dmrr.838. PMID: 18386798.

2. Beyaz S, Güler ÜÖ, Bağır GŞ. Factors affecting lifespan following below-knee amputation in diabetic patients. Acta Orthop Traumatol Turc. 2017 Oct;51(5):393-397. doi: 10.1016/j.aott.2017.07.001. Epub 2017 Aug 31. PMID: 28865844; PMCID: PMC6197166.
3. Petrakis I, Kyriopoulos IJ, Ginis A, Athanasakis K. Losing a foot versus losing a dollar; a systematic review of cost studies in diabetic foot complications. Expert Rev Pharmacoecon Outcomes Res. 2017 Apr;17(2):165-180. doi: 10.1080/14737167.2017.1305891. Epub 2017 Mar 17. PMID: 28283002.

4. Park SY, Rhee SY, Chon S, Ahn KJ, Kim SH, Baik SH, Park Y, Nam MS, Lee KW, Woo JT, Chun KH, Kim YS; KNDP study investigators. Effects of foot complications in patients with Type 2 diabetes mellitus on public healthcare: An analysis based on the Korea National Diabetes Program Cohort. J Diabetes Complications. 2017 Feb;31(2):375-380. doi: $\quad$ 10.1016/j.jdiacomp.2016.06.024. Epub 2016 Jun 29. PMID: 27445007.

5. Pemayun TGD, Naibaho RM. Clinical profile and outcome of diabetic foot ulcer, a view from tertiary care hospital in Semarang, Indonesia. Diabet Foot Ankle. 2017 May 17;8(1):1312974. doi: 10.1080/2000625X.2017.1312974.

PMID: 28649296; PMCID: PMC5475294.

6. Vibha SP, Kulkarni MM, Kirthinath Ballala AB, Kamath A, Maiya GA. Community based study to assess the prevalence of diabetic foot syndrome and associated risk factors among people with diabetes mellitus. BMC Endocr Disord. 2018 Jun 26;18(1):43. doi: $\quad 10.1186 / \mathrm{s} 12902-018-0270-2$. PMID: $\quad 29940924$; PMCID: PMC6020220.

7. Akila M, Ramesh RS, Kumari MJ. Assessment of diabetic foot risk among diabetic patients in a tertiary care hospital, South India. J Educ Health Promot. 2021 Jan 28;10:14. doi: 10.4103/jehp.jehp_407_20. PMID: 33688523; PMCID: PMC7933675.

8. Janmohammadi N, Hasanjani Roshan MR, Rouhi M, Esmailnejad Ganji SM, Bahrami M, Moazezi Z. Management of diabetic foot ulcer in Babol, North of Iran: an experience on 520 cases. 
Caspian J Intern Med. 2012 Summer;3(3):456-9. PMID: 24009914; PMCID: PMC3755850.

9. Klaphake S, de Leur K, Mulder PG, Ho $\mathrm{GH}$, de Groot HG, Veen EJ, Verhagen HJ, van der Laan L. Mortality after major amputation in elderly patients with critical limb ischemia. Clin Interv Aging. 2017 Nov 22;12:1985-1992. doi: 10.2147/CIA.S137570. PMID: 29200838 ; PMCID: PMC5702177.

10. Chawla A, Chawla R, Jaggi S. Microvasular and macrovascular complications in diabetes mellitus: Distinct or continuum? Indian J Endocrinol Metab. 2016 JulAug;20(4):546-51. doi: 10.4103/22308210.183480. PMID: 27366724; PMCID: PMC4911847.

11. Al-Rubeaan K, Al Derwish M, Ouizi S, Youssef AM, Subhani SN, Ibrahim HM, Alamri BN. Diabetic foot complications and their risk factors from a large retrospective cohort study. PLoS One. 2015 May 6;10(5):e0124446. doi: 10.1371/journal.pone.0124446. PMID: 25946144; PMCID: PMC4422657.

12. Zhang SS, Tang ZY, Fang P, Qian HJ, $\mathrm{Xu}$ L, Ning G. Nutritional status deteriorates as the severity of diabetic foot ulcers increases and independently associates with prognosis. Exp Ther Med. 2013 Jan;5(1):215-222. doi: 10.3892/etm.2012.780. Epub 2012 Oct 30. PMID: 23251271; PMCID: PMC3524099.

13. Abdissa D, Adugna T, Gerema U, Dereje D. Prevalence of Diabetic Foot Ulcer and Associated Factors among Adult Diabetic Patients on Follow-Up Clinic at Jimma Medical Center, Southwest Ethiopia, 2019: An Institutional-Based Cross-Sectional Study. J Diabetes Res. 2020 Mar 15;2020:4106383. doi: 10.1155/2020/4106383. PMID: 32258165; PMCID: PMC7102459.

14. Mariam TG, Alemayehu A, Tesfaye E, Mequannt W, Temesgen K, Yetwale F, Limenih MA. Prevalence of Diabetic
Foot Ulcer and Associated Factors among Adult Diabetic Patients Who Attend the Diabetic Follow-Up Clinic at the University of Gondar Referral Hospital, North West Ethiopia, 2016: Institutional-Based Cross-Sectional Study. J Diabetes Res. 2017;2017: 2879249. doi: 10.1155/2017/2879249. Epub 2017 Jul 16. PMID: 28791310; PMCID: PMC5534295.

15. Abolfotouh MA, Alfaifi SA, Al-Gannas AS. Risk factors of diabetic foot in central Saudi Arabia. Saudi Med J. 2011 Jul;32(7):708-13. PMID: 21748208.

16. Al-Maskari F, El-Sadig M. Prevalence of risk factors for diabetic foot complications. BMC Fam Pract. 2007 Oct 10;8:59. doi: 10.1186/1471-2296-859. PMID: 17927826; PMCID: PMC2174471.

17. Benotmane A, Mohammedi F, Ayad F, Kadi K, Azzouz A. Diabetic foot lesions: etiologic and prognostic factors. Diabetes Metab. 2000 Apr;26(2):113-7. PMID: 10804325.

18. Abbott CA, Carrington AL, Ashe $\mathrm{H}$, Bath S, Every LC, Griffiths J, Hann AW, Hussein A, Jackson N, Johnson $\mathrm{KE}$, Ryder $\mathrm{CH}$, Torkington $\mathrm{R}$, Van Ross ER, Whalley AM, Widdows P, Williamson S, Boulton AJ; North-West Diabetes Foot Care Study. The NorthWest Diabetes Foot Care Study: incidence of, and risk factors for, new diabetic foot ulceration in a communitybased patient cohort. Diabet Med. 2002 May;19(5):377-84. doi: 10.1046/j.14645491.2002.00698.x. PMID: 12027925.

19. Nongmaithem M, Bawa AP, Pithwa AK, Bhatia SK, Singh G, Gooptu S. A study of risk factors and foot care behavior among diabetics. J Family Med Prim Care. 2016 Apr-Jun;5(2):399-403. doi: 10.4103/2249-4863.192340. PMID: 27843849; PMCID: PMC5084569.

20. Chatwin KE, Abbott CA, Boulton AJM, Bowling FL, Reeves ND. The role of foot pressure measurement in the prediction and prevention of diabetic foot ulceration-A comprehensive 
review. Diabetes Metab Res Rev. 2020

May;36(4):e3258.

doi:

10.1002/dmrr.3258. Epub 2019 Dec 11.

PMID: $\quad 31825163$; PMCID:

PMC7317473.

21. Thewjitcharoen Y, Krittiyawong S, Porramatikul S, Parksook W, Chatapat L, Watchareejirachot O, Sripatpong J, Himathongkam T. Outcomes of hospitalized diabetic foot patients in a multi-disciplinary team setting: Thailand's experience. J Clin Transl Endocrinol. 2014 Oct 15;1(4):187-191. doi: 10.1016/j.jcte.2014.10.002. PMID: 29159100; PMCID: PMC5685051.

22. Fife CE, Horn SD, Smout RJ, Barrett RS, Thomson B. A Predictive Model for Diabetic Foot Ulcer Outcome: The Wound Healing Index. Adv Wound
Care (New Rochelle). 2016 Jul 1;5(7):279-287. doi: 10.1089/wound.2015.0668. PMID: 27366589 ; PMCID: PMC4900227.

23. Vassar M, Holzmann M. The retrospective chart review: important methodological considerations. J Educ Eval Health Prof. 2013 Nov 30;10:12. doi: 10.3352/jeehp.2013.10.12. PMID: 24324853; PMCID: PMC3853868.

How to cite this article: Prakash V. Clinical profile of patients with diabetic foot ulcer treated conservatively or surgically and effect of risk factors on ulcer healing. International Journal of Research and Review. 2021; 8(6): 238-244. DOI: https:// doi.org/10.52403/ijrr.20210629 